\title{
Turkic Instrumental Case Marker in Tātic Language Group
}

\author{
Mohammad Rasekh-Mahand \& Raheleh Izadifar*
}

\begin{abstract}
This paper studies the morphological influence of language contact between Turkic and Tātic language group in Northwest Iran. The postposition under study is the Turkic -inan and how it has entered the morphological system of some Tāti dialects of Iran. In particular, it is shown which Tāti dialects are influenced in this regard and why. The data for this study were collected from interviews with native Tāti and Turkic speakers in Iran and also from descriptive grammars and Tāti-Farsi dictionaries. We have used Narrog's (2010) instrumental semantic map to see which semantic functions are fulfilled with the instrumental-related postposition or case marker in both Tāti and Turkic dialects of Iran and whether they are the same or different in these languages.
\end{abstract}

1. Introduction. Speakers of Turkic and Iranian languages have been in contact since pre-Islamic times (Perry 2001: 193). The influx of massive Turkish-speaking populations and their settlement in large areas of Iran particularly in Azerbaijan and the northwest Iran, progressively turkicized local speakers of Persian, Kurdish and other Iranian languages including Tāti dialects spoken in northwest Iran. This process peaked with the accession of the Safavid Shah Esma'il in 1501 C.E in Azerbaijan. He and his successors who were Turkishs peaking, accepted and promoted written Persian as the established language of bureaucracy and literature, but they and their tribal supporters habitually spoke Turkish in court and camp and this fact brought an unprecedented prestige for the Turkish vernacular of Iran. As a result, the domains of usage of this vernacular expanded and a competition between Turkish and Iranian languages began in many areas of Iran including Azerbaijan (cf. Perry 2001: 193).

Borrowing or copying of vocabulary by one or both pertinent languages is the most obvious result of language contact. Among the less obvious effects are changes in the sound system or syntactic structures, sometimes involving the loss, and sometimes the acquisition, of a feature. In eastern Anatolia and Azerbaijan, Turkic (the language of imperial and local rulers and subjects) has had effects on the neighboring Iranian languages including Kurdish, Tāti, and local varieties of Persian chiefly in lexical loans, and by direct spoken interaction. Such cases of mainly vernacular result from the bilingualism of intermingled populations. They are often asymmetrical: the subordinate speech community (such as Tāti) tends to become bilingual and to undergo more linguistic change than the other (cf. Perry 2006).

The Iranian languages that are most strongly subject to Turkic influence are Kurdish and some dialects of Tâti and Tâlyshi in Azerbaijan. It has even been argued that the verb systems of the latter two have been changing from an Iranian to a more Turkic type (Perry 2006; Stilo 1981; Windfuhr 1987).

Assessing the degree of contact influence in Tāti in this research is a delicate matter, for it involves comparing the supposedly contact-induced form with some postulated "pure" more conservative corresponding form. In the case of Tâti, isolating a neutral "norm" is particularly difficult. The Tâti dialects have differences with each other even in dialects of nearby neighboring villages and these villages are dispersed in a large area. In addition, Tāti dialects are among the definitely endangered languages of Iran (cf. http://www.unesco.org/languages-atlas/index.php) as the official language of the country and media is Persian and the vernacular in many areas in Northwest Iran is Turkic. Another reason for the endangerment of Tâti dialects is that the young parents do not talk Tâti to their children as they want them

\footnotetext{
*Authors: Mohammad Rasekh-Mahand, Bu-Ali Sina University (mrasekhmahand@yahoo.com) \& Raheleh Izadifar, Bu-Ali Sina University (raheleh.izadifar@gmail.com)
} 
to learn Persian and get ready for school. Multilingualism and bilingualism are therefore intrinsic to the Tāti speech community and finding monolingual Tāti speakers or dialects against which contact influence could be gauged is very hard.

Our primary aim here is to present original data acquired from questionnaires and illustrative examples of particular contact phenomena which have happened in Tāti dialects. As a rough means of assessing the extent of contact influence, the Tāti-Turkic-Persian varieties are compared to the Tāti-Persian ones, not much subject to direct influence from Turkic. In order to do this, we studied and compared the Tāti varieties of Esfarvarini, Tākestāni, Eshtehārdi, and Vafsi of the Southern Tāti group, and Karnaqi and Dəravi of the Central Tāti group with the Shāhrudi variety of Turkic spoken in Iran. The data for this study is gathered through a questionnaire of 70 sentences in Persian which included different adpositions and we asked the participants to translate these sentences into Tāti and/or Turkic and write the translations in the questionnaire. While the Southern Tāti participants were Tāti-Persian bilinguals, the Central Tāti participants were Tâti-Turkic-Persian trilinguals. Also, while the Turkic speakers of Shāhrudi were trilinguals of Tâti-Turkic-Persian, the speakers of Turkic in Hamedan were Turkic-Persian bilinguals.

2. Linguistic Background. The present paper studies a functional element which has high cross-dialectal variation among Tāti dialects. This element which is used for instrumental-related functions, is considered a native element in some Tāti varieties and borrowed in still others. Therefore, the linguistic background of both Tâtic and Turkic languages will be discussed in this section.

2.1. TĀTIC. In northwest areas of Iran, there are still a few remote clusters of Iranian languages called Tâti. These languages are among Northwest Iranian languages which are descended from older stages of Iranian languages. Tāti villages and cities form, generally, isolated pockets surrounded by Turkic-speaking areas.

The Tātic family consists of: A) highly diverse Täti (Tati) dialects that are sparsely spread over a discontinuous area extending from Vafsi in the south near Saveh to Kilit (now extinct) of Nakhichevan/ Naxjavān province of the Republic of Azerbaijan north of the Araxes; B) Tālyshi ranging from the northernmost dialect of the Masally area of Azerbaijan to the Rudbār valley in Iran; and C) "Tātoid", two Tāti-like offshoots, Rudbāri and Tāleqāni/Alamuti. These sub-groups and varieties are summarized in the following list and are shown in map 1 below. The numbers in parenthesis refer to the numbering in Fig.1 below (Stilo 1981: 138-141, Stilo 2018: 659-660):

$$
\begin{aligned}
& \text { Tātic } \\
& \text { Tāti } \\
& \text { Southern Tāti (1) } \\
& \text { Central Tāti (2) } \\
& \text { Northern Tāti (3) } \\
& \text { Tālyshi (4) } \\
& \text { S. Tālyshi } \\
& \text { C. Tālyshi } \\
& \text { C. -N. transitional } \\
& \text { N. Tālyshi } \\
& \text { Tātoid (5) } \\
& \text { Tāleqāni-Alamut Tātoid } \\
& \text { Rudbār Tātoid }
\end{aligned}
$$

Figure 1. Classification of Tātic dialects 
While the Tâlysh population is quite dense and forms a classic dialect chain extending southwards from Azerbaijan to Iran, the Tāti languages are disjointed and dispersed in northwestern provinces of Iran including Markazi, Qazvin, Zanjān, Ardebil, East Azarbaijan and Gilan provinces (For details of Tātic grouping see Stilo 1981: 140-141, Stilo 2018: 664).

Locations of Tātic varieties are shown in figure (2). The numbers show the rough location of Tātic groups in northwest Iran as follows: Southern Tāti (1), Central Tāti (2), Northern Tāti (3), Tālyshi (Tāleši) (4), and Rudbār Tātoid (5).
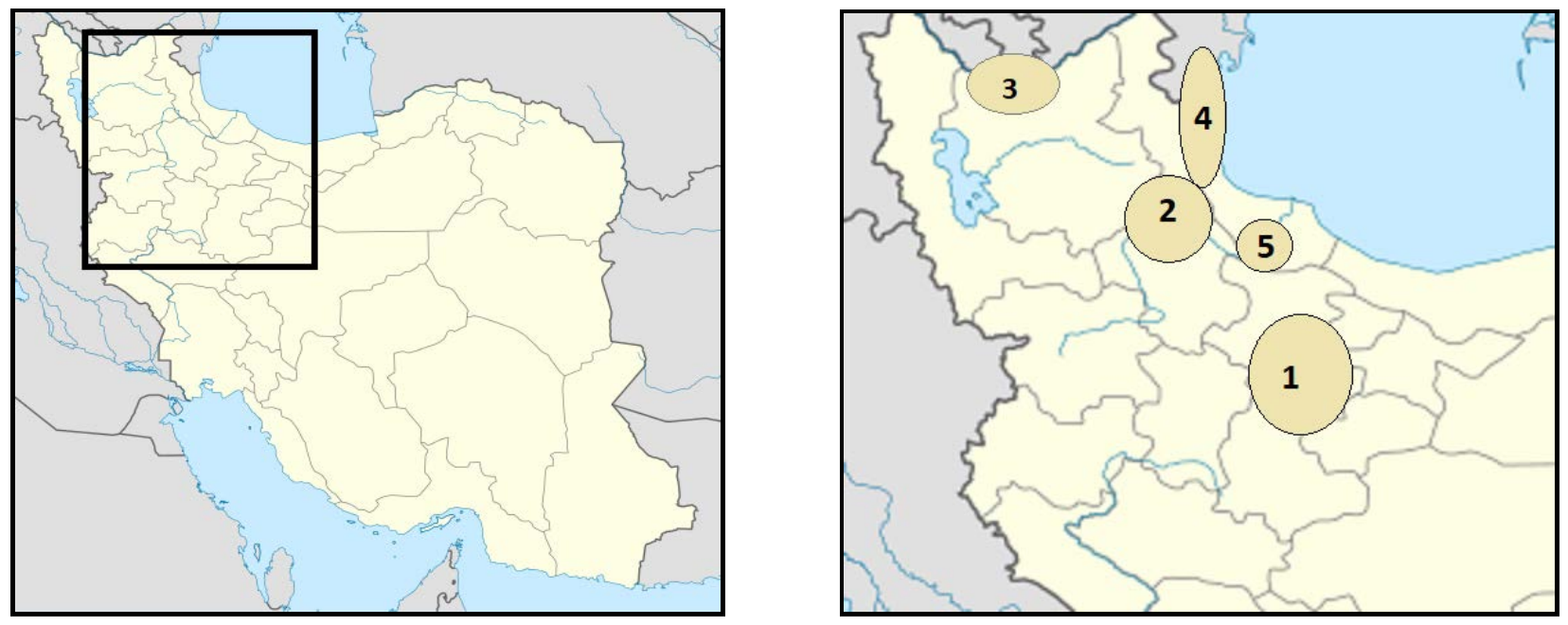

Figure 2. Locations of Tātic varieties in Northwest Iran

2.2. TURKIC. For nearly a millennium, Turkic has been spoken widely in Northwestern areas in Iran. The Turkic varieties of Azerbaijan provinces in Iran are among the western or Saljuqian branch of the Oghuz branch of the Turkic language family. During the $11^{\text {th }}$ century, their speakers followed the Saljuq's migration from Central Asia into Iran, Iraq and Anatolia; for roughly four hundred years thereafter they formed part of the tribal confederations dominating the greater area of Iran (Bulut 2018; Doerfer 2011: 245). The longstanding contact among Turkic varieties and Iranian languages has had many influences on both sides.

Among the Tāti-speaking areas, the Northern and Central Tâti groups were bilingual speakers of Turkic-Tāti in past and are trilingual speakers of Turkic-Tāti-Persian in recent decades although the Northern group Tāti is highly endangered and has very few speakers in remote villages; On the other hand, the Southern Tâti speakers have not had much contact with the Turkic varieties spoken in their adjacency and have not been much influenced by Turkic.

3. Theoretical Background. The instrumental-related postposition shows considerable variation among the Tāti dialects. This postposition is native in some Tāti dialects but others have replaced this with a borrowed postposition which is native to Turkic varieties of Iran. The theoretical background of this research including borrowing adpositions and instrumental semantic map will be discussed in this section.

3.1. BORROWING ADPOSITIONS. Adpositions are roughly, grammatical elements which mark the relationship between two parts of a clause. Adpositions lie at the border between grammar and lexicon and are often involved in complex syntactic relationships such as encoding of arguments, government of 
case-marked nouns etc. Adpositions can be closed classes, open classes, or non-existent in particular languages. According to Hagège (2010: 8): "An adposition (Adp) is an unanalyzable or analyzable grammatical word constituting an adpositional phrase (Adp-phrase) with a term that it puts in relationship, like case affixes, with another linguistic unit, by marking the grammatical and semantic links between them".

The literature on language contact has noted that with respect to lexical borrowing, content items are more likely to be borrowed than function items. As a result, there seem to be constraints on borrowing. Such constraints have often been interpreted as implicational universals. Several hierarchies, well known as borrowability scales, have been proposed, allowing for generalizations with respect to the susceptibility of various linguistic categories to contact induced change. Such scales predict that borrowing of function words is less frequent and more constrained than borrowing of content items. Much of the research on borrowing is focused on the borrowing of content words or on the borrowing of grammatical patterns. These borrowoability scales are considered implicational universals. Thus, according to Field 2002:

content item $>$ function word $>$ agglutinating affix $>$ fusional affix

And according to Matras 2007:61 the following scale is observed:

Nouns, conjunctions $>$ verbs $>$ discourse markers $>$ adjectives $>$ interjections $>$ adverbs $>$ other particles, adpositions $>$ numerals $>$ pronouns $>$ derivational affixes $>$ inflectional affixes

Adposition borrowing is not extremely common in world languages and as a result is considered interesting among linguists and typologists. In the borrowing hierarchy, adpositions are generally located somewhere in the middle. The location of adposition in the middle of the hierarchy predicts that they will be rather resistant to borrowing compared to other types of lexical and grammatical items.

3.2. INSTRUMENTAL SEMANTIC MAP. Semantic maps are tools which represent cross-linguistic regularities in the mapping of meaning on form (Narrog and Ito 2007: 273). These maps are used as tools for representing the polyfunctionality of words and constructions (Auwera 2013: 154). Polyfunctionality is prominent with grammatical morphemes including affixal categories and function words and these morphemes have more abstract and general meanings and thus, are more apt to be used in multiple ways than content words (Haspelmath 2003: 211). Semantic maps are used for representing language universals and language-specific grammatical knowledge (Croft 2003: 133).

The present paper investigates functions of instrumental marker in some Tăti dialects and how the longstanding contact with Turkic has influenced the instrumental marker in these dialects. To do this, Narrog's instrumental semantic map (Narrog 2010: 243) is used as the basis for analyzing instrumentalrelated functions in these languages. Figure (3) shows the proposed map by Narrog. This map is a diachronic one, and the arrows show directions of change between meanings. In this map, instrumental and companion are the core functions; their polysemy is the largest across language phyla and nearly all other functions are evolved from these functions. The instrumental semantic map may contain implicational universals, for example, if a marker encodes instrumental and recipient, it should also encode companion, which is between these two functions on the map. It is worth noting that the markers should cover what is called connectivity, proximity, or adjacency in the literature (Croft 2003; Haspelmath 2003; Auwera and Plungian 1998).; In other words, connected regions should be covered on the map. 


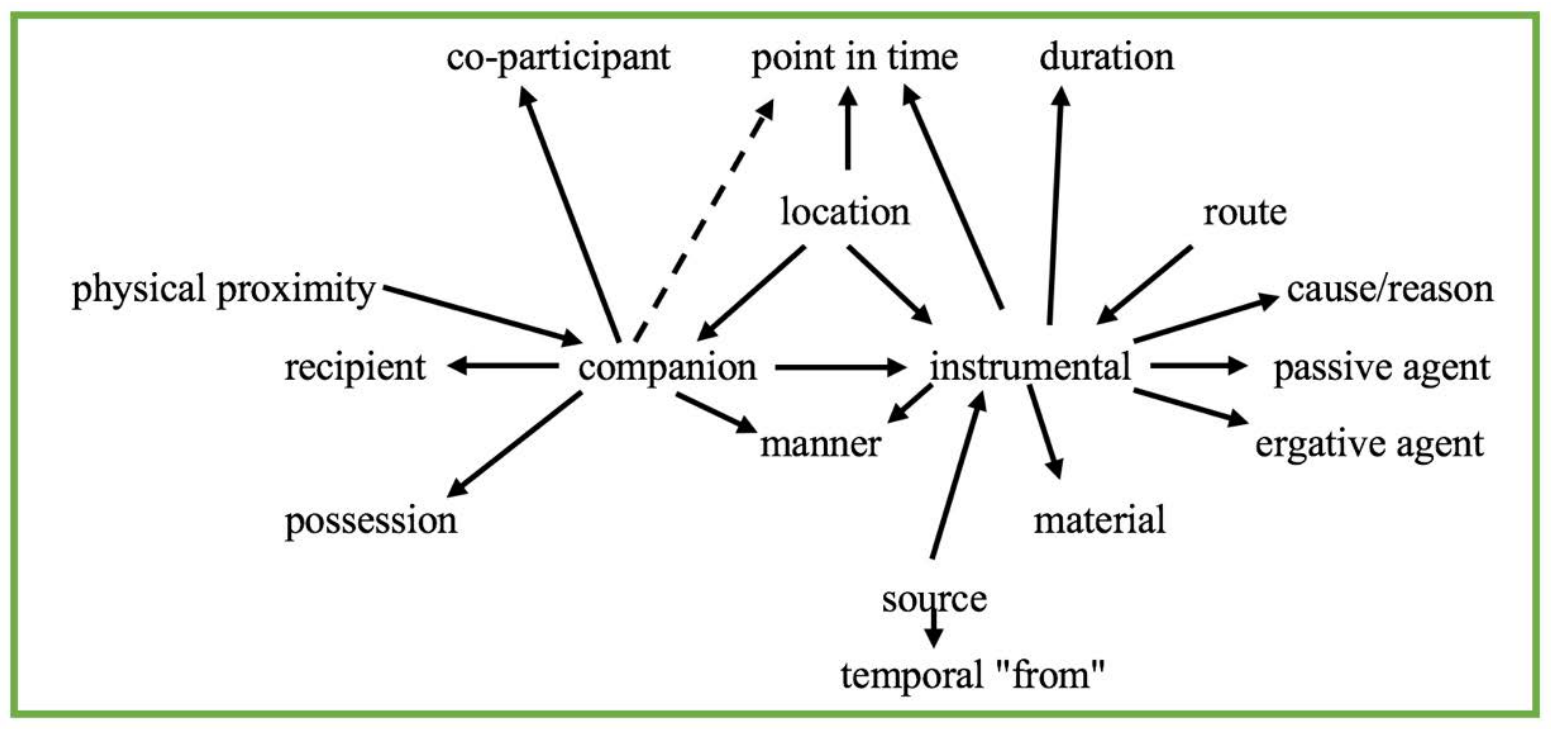

Figure 3. Narrog's (2010) Instrumental Semantic Map

4. Data Collection. After a preliminary study of the previous literature on adpositions in Tātic dialects, we prepared a questionnaire of 70 ordinary sentences containing different adpositions in Persian and we sent the questionnaire in email or whatsapp and asked our consultants to write the Tāti or Turkic translation of the Persian sentences in the questionnaire and send it back to us. The consultants were all young or middle-aged literate fluent speakers and learned Tāti and/or Turkic in childhood as mother language. We received the completed questionnaire for the following dialects:

- 4 Southern Tāti dialects: Esfarvarini, Tākestāni, Eshtehārdi, Vafsi

- 3 Central Tāti dialects: Karnaqi, Dəravi, Kuluri

- 2 Turkic dialects of Northwest Iran: Shāhrudi, Hamedāni

5. Data Analysis. A distinctive feature of Tâti dialects is the frequent use of postpositions with indirect objects (Yar-Shater 1969-b: 1). Prepositions are rare in these dialects and generally are of borrowed origin, appearing chiefly in affected speech. Yar-Shater (1969-b) has discussed the postpositions employed in Southern Tāti. He has also briefly discussed the postpositions in Northern Tāti for supplementary information. According to Yar-Shater (1969-b: 2) all postpositions are unstressed. They may follow a noun or a pronoun. When a noun is followed by both an enclitic pronoun and a postposition, the pronoun precedes the postposition. The object of a postposition is generally expressed in the oblique case.

In this section we will study the instrumental-related functions in different Tāti and Turkic varieties spoken in Northwest Iran. We will see how the same sentence in the questionnaire is said in different Tāti dialects and thus, how the Southern and Central Tāti dialects are different in using the instrumental-related functions.

5.1. SOUTHERN TĀTI. In this subsection, we will first consider the Tākestāni, Esfarvarini, Eshtehārdi, and Vafsi varieties of Southern Tâti to see what postposition is used for instrumental-related functions in these dialects. The native Tāti postpositons are preserved for instrumental-related senses in Southern Tāti. For instance, the instrumental-related postposition is (e)ndu 'with, in' and $u$ in Chāli, $b i$ 'with' in Tākestāni, beja ' 'with' in Eshtehārdi, and vari 'with' in Dānesfahāni. The postosition na(n) 'with', is absent 
in Southern Tāti and is found in Kahali, Karani, Lerdi, Kajali and Geylavāni, spoken in Khalkhāl. The final $-n$ is weak in Kahali, Karani, and Lerdi, and disappears in Kajali.

In some Southern Tāti dialects, the oblique case marker is used for instrumental-related functions. For instance, in Esfarvarini dialect the feminine direct and oblique case marker $-a$ is used for instrumental function as in example $(1-a, b)$ and material as in example (1-c). The postposition hamberā is used for most of other instrumental-related functions in this dialect.

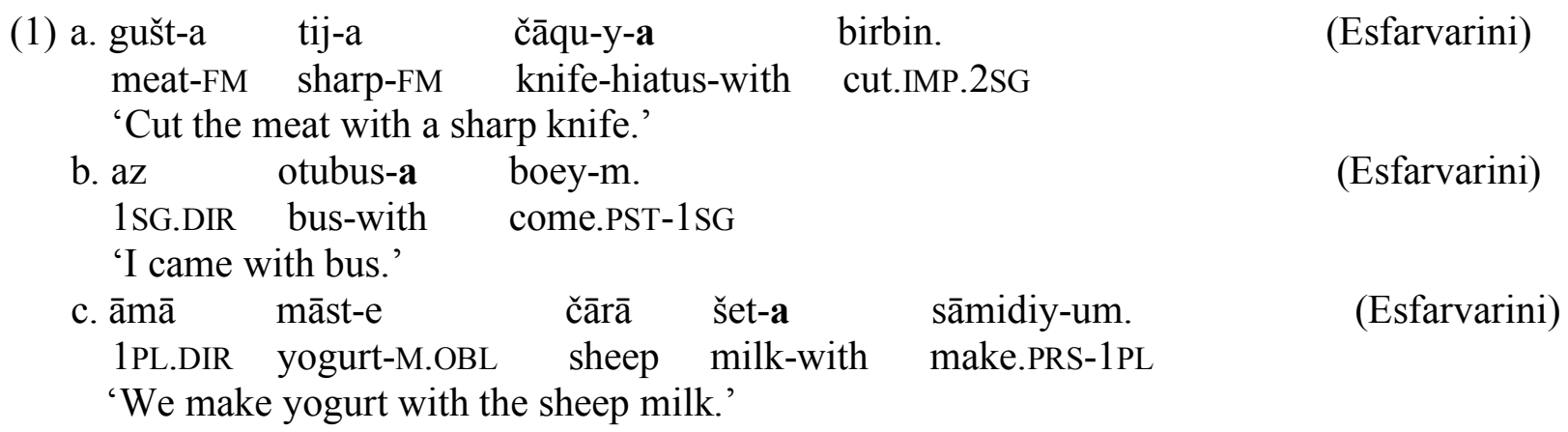

In some Southern Tāti dialects such as Tākestāni, the postposition bi/vi is used for instrumentalrelated functions. This postposition is used for instrumental (e.g. 2-a), companion (e.g. 2-b), coparticipant (e.g. 2-c), and manner (e.g. 2-d).

(2) a. gušt-e tiz-e čāqu bi birbin.

meat-OBL sharp-EZ knife with cut.IMP.2SG

(Tākestāni)

'Cut the meat with a sharp knife.'

b. a amad-e vi meš-em.

1SG.DIR PN-OBL with go.PRS-1SG

'I go with Ahmad.'

c. hasan amad-e bi vāzi mi-yare.

PN.DIR PN-OBL with game CONT-do.PRS.3SG

'Hasan plays with Ahmad.'

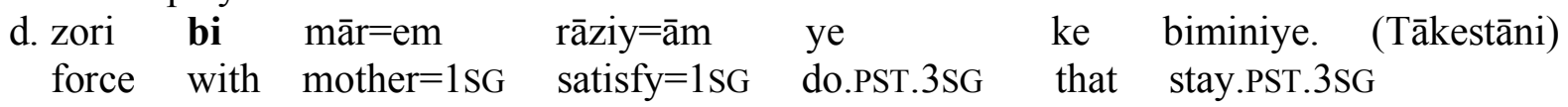

'In a hard way I satisfied my mother to stay.'

In some southern Tāti dialects such as Eshtehārdi, the instrumental-related functions are

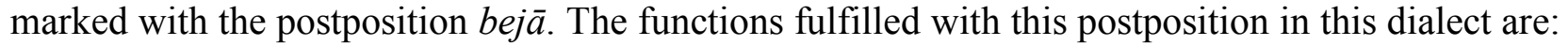
instrumental (e.g. 3-a), companion (e.g. 3-b), co-participant (e.g. 3-c), manner (e.g. 3-d), and material (e.g. 3-e).

(3) a. gušt-e tij-a čāqu bejā pāra ka. meat-OBL.MS sharp-DIR.FM knife with torn do.IMP.2SG

(Eshtehārdi)

'Cut the meat with a sharp knife.'

b. az ahmad-e bejā mišem.

$1 \mathrm{SG}$ PN-OBL.MS with go.PRS.1SG

'I go with Ahmad.'

c. hasan ahmad-e bejā vāzi mikara.

PN PN-OBL.MS with game do.PRS.3SG

(Eshtehārdi)

'Hasan plays with Ahmad.' 

d. zur-e bejā naniy=ām rāzi=m kard bemuna. (Eshtehārdi) force-OBL.MS with mother=1SG satisfy $=1 \mathrm{SG}$ do.PST.3SG stay.SUBJ.3SG
'In a hard way I satisfied my mother to stay.'
e. čamā māsta gesfend-ā šira bejā čā mikarun. 1PL yogurt sheep-OBL.FM milk with make do.PRS-1PL
'We make yogurt with the sheep's milk.'

Yet in some other Southern Tāti dialects, more functions are marked with the instrumental postpositions. In Vafsi, for instance, $r \bar{a}$ is used to mark the following functions: instrumental (e.g. 4-a), companion (e.g. 4-b), co-participant (e.g. 4-c), manner (e.g. 4-d), material (e.g. 4-e), and recipient/addressee (e.g. 4-f).

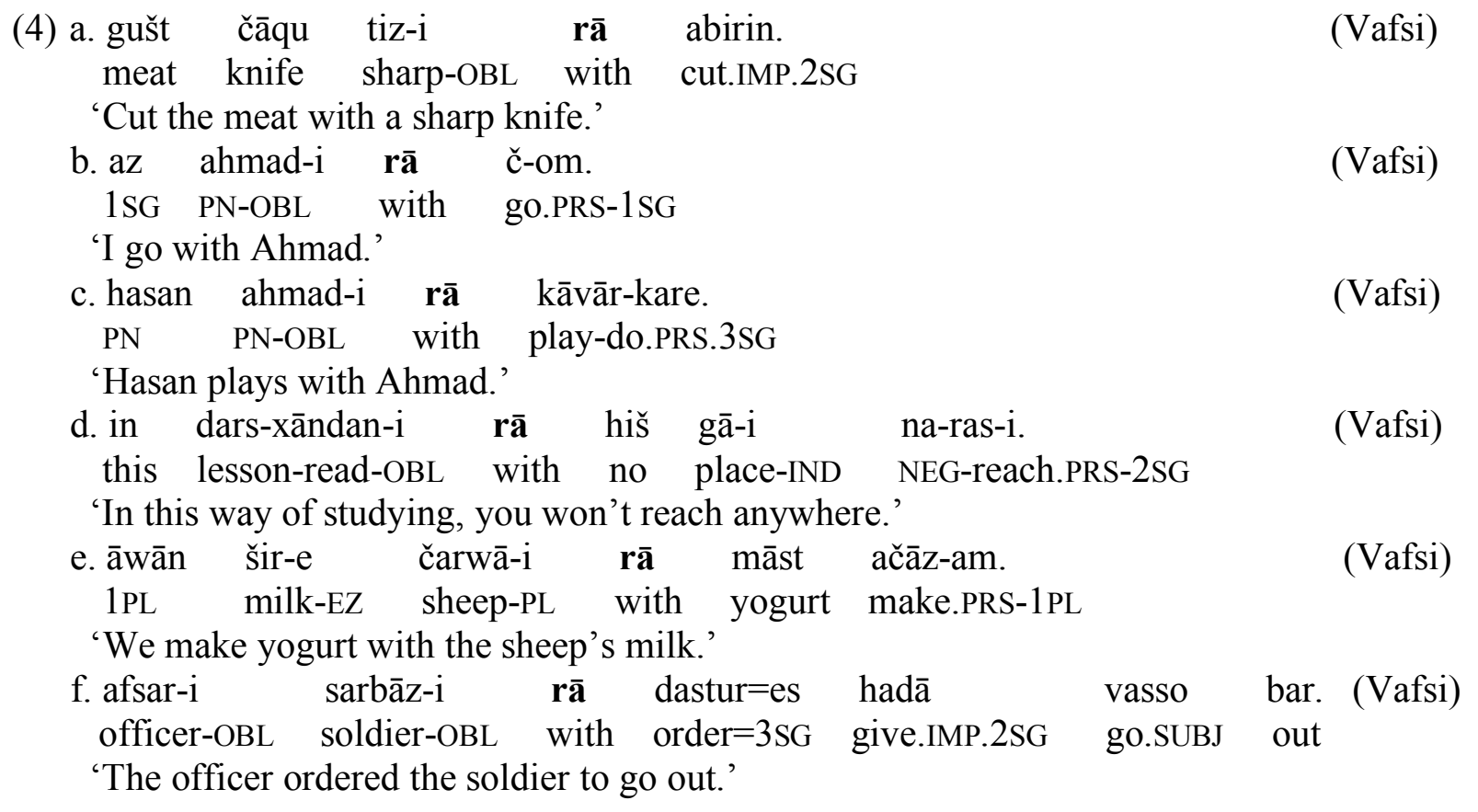

To summarize this subsection, the Southern Tāti data showed that the postpositions used for instrumental-related functions in these dialects are native to these dialects. As Yar-Shater (1969-a: 21) states: "The vernacular common to the regions is Azerbaijani Turkish, and only Rāmand contains a majority of Tāti speakers." The participants of this study who speak Southern Tâti dialects were not speaking Turkic and the postpositions used in their questionnaire are native to Tâti and have not been influence from Turkic. Figure (4) illustrates boundaries of $-a$ in Esfarvarini (the orange rectangle), $b i / v i$ in Tākestāni (the boundaries in the blue lines), bejā in Eshtehārdi (the boundaries in the green lines), and $r \bar{a}$ in Vafsi (the boundaries in the red lines). 


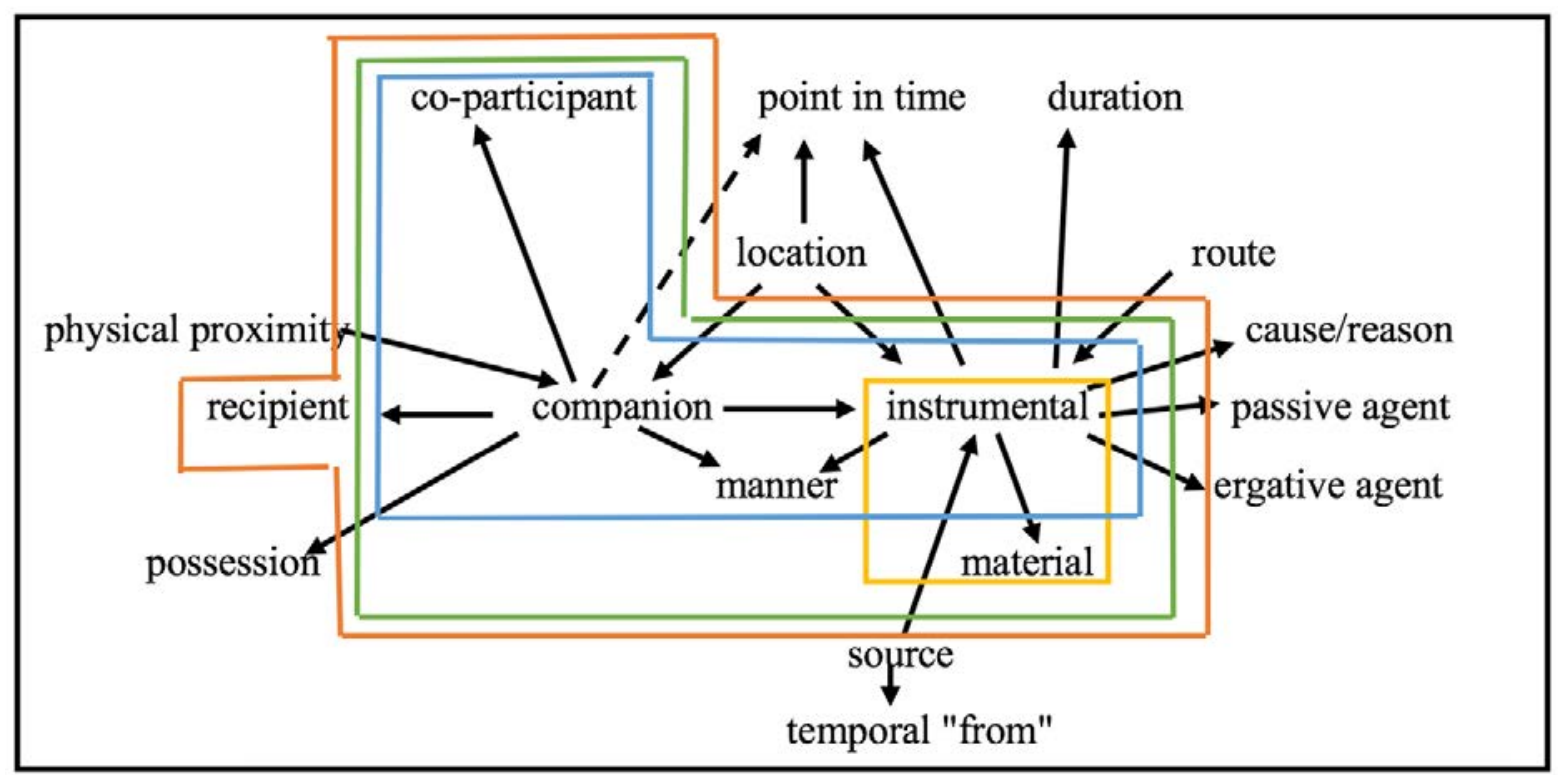

Figure 4. Boundaries of instrumental-related markers in Southern Tāti dialects

5.2. Central TĀTI. In this subsection we will consider the data from the Shāhrudi group of Central Tāti. The instrumental-related functions in these dialects are marked with the postposition nan in some Central Tâti dialects such as Karnaqi and Koluri, and with the postposition na in some Central Tāti dialects such as Dəravi. In Karnaqi, nan is used to mark instrumental (e.g. 5-a), companion (e.g. 5-b), co-participant (e.g. 5-c), manner (e.g. 5-d), material (e.g. 5-e), and recipient/addressee (e.g. 5-f).

(5) a. tij-a čāqu

nan gušt beber.

(Karnaqi) sharp-EZ knife with meat cut.IMP.2SG

'Cut the meat with a sharp knife.'
b. az ahmad-e nan šim.
1SG.DIR PN-OBL with go.PRS.1SG
'I go with Ahmad.'
c. hasan ahmad-e nan bāzi karda kare. PN PN-OBL with game do CONT.PRS.3SG

(Karnaqi)

(Karnaqi)

'Hasan plays with Ahmad.'

d. em darsa-xāni nan hiš yāgā āne-ras-i. this lesson-read with no place NEG-reach.PRS-2SG

(Karnaqi)

'In this way of studying, you won't reach anywhere.'
e. āmā qāteq-e pass-e šet-e nan čā karām. $1 \mathrm{PL}$ yogurt-OBL sheep-OBL milk-OBL with make do.PRS-1PL

'We make yogurt with the sheep's milk.'

$\begin{array}{lllllll}\text { f. man } & \text { nan } & \text { komak } & \text { beka } & \text { āru } & \text { mehmān } & \text { dārem. } \\ \text { 1SG.OBL } & \text { with } & \text { help } & \text { do.IMP.2SG } & \text { today } & \text { guest } & \text { have.PRS.1SG }\end{array}$

'Help me, I have guest(s) today.'

In some other Central Tāti dialects, nan has been shortened to na and fulfills more functions. In Dəravi for instance, $n a$ is used to mark the following functions: instrumental (e.g. 6-a), 
companion (e.g. 6-b), co-participant (e.g. 6-c), manner (e.g. 6-d), material (e.g. 6-e), recipient/addressee (e.g. 6-f), and cause/reason (e.g. 6-g).
(6) a. gušt-ə tərij-a kārd-a na banjan.
meat-OBL sharp-EZ knife-EZ with cut.IMP.2SG
'Cut the meat with a sharp knife.'
b. az amad-ə
na šum.
1SG.DIR PN-OBL with go.PRS.1SG
'I go with Ahmad.'
c. hasan amad-ə na məzā karə. PN PN-OBL with game do.PRS.3SG
(Dəravi)
(Dəravi)
'Hasan plays with Ahmad.'
d. om darsa-xanden
na hiji-gā ābə-ras-i.
this lesson-read with no-place NEG-reach.PRS-2SG
(Dəravi)
'In this way of studying, you won't reach anywhere.'
e. ama mās-ə pas-a šət-ə na reč ākaram.
1PL yogurt-OBL sheep-EZ milk-OBL with make do.PRS-1PL
(Dəravi)
'We make yogurt with the sheep's milk.'
f. čemān na bāj māndo.
1SG.OBL with tell.IMP.2SG NEG.come.SUBJ
'Tell them not to come.'

\begin{tabular}{|c|c|c|c|c|c|c|}
\hline $\begin{array}{l}\text { g. ilāhi } \\
\text { God }\end{array}$ & $\begin{array}{l}\text { javān.marg } \\
\text { young.death }\end{array}$ & $\begin{array}{l}\text { bəbi } \\
\text { become.SUBJ.2SG }\end{array}$ & $\begin{array}{l}\text { əŠtə } \\
\text { 2SG.POSS }\end{array}$ & $\begin{array}{l}\text { om } \\
\text { this }\end{array}$ & $\begin{array}{l}\text { šupar } \\
\text { hushand }\end{array}$ & na. (Dəravi) \\
\hline
\end{tabular}

(Dəravi)

Borrowed adpositions are often integrated into the same case patterns as inherited ones, therefore, it is predictable that once $n a(n)$ is borrowed into Central Tāti dialects, it is replaced for the inherited postposition and fulfills the same functions that the previous native postposition indicated before borrowing happened.

To summarize this subsection, the Central Tāti data showed that the postpositions used for instrumental-related functions in these dialects are not native to these dialects and are of borrowed origin. The people who speak Central Tāti dialects are trilingual speakers of Tāti, Turkic and Persian, As Yar-Shater (1960-a: 21) states: "The vernacular common to the region is Azerbaijani. In Tāti-speaking villages the population is generally trilingual, speaking Tāti, Persian, and Turkish." and the Tâti dialects have been influenced from Turkic both in vocabulary and grammar. Figure (5) illustrates boundaries of nan in Karnaqi (the boundaries in the red lines) and na in Doravi (the boundaries in the blue lines). 


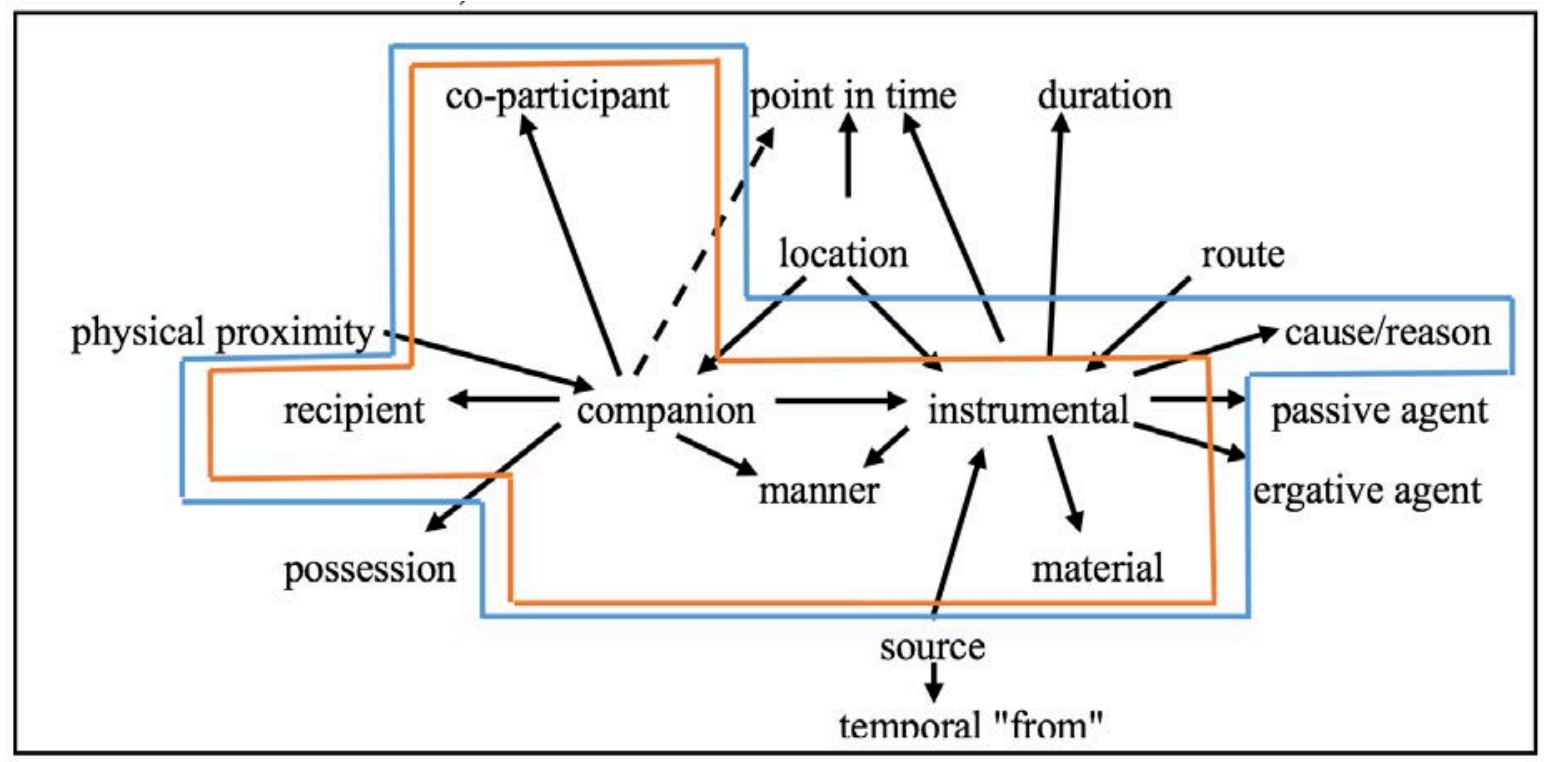

Figure 5. Boundaries of instrumental-related markers in Central Tāti dialects

5.3. NORTHERn TĀTI. The data for Northern Tāti is not much as these dialects are highly endangered or almost extinct. Thus, we couldn't have the questionnaire in any of these dialects. But the few available data from the Harzani dialect of this subgroup shows that the postposition -hun, which is a native Tāti element, is used in most instances for instrumental-related functions. e.g.,

(7) a. a man-e hun tehrun šeraniya.

3SG.DIR 1SG-OBL with PN go.PRS.3SG

'S/He will go to Tehran with me.' (Sabzalipur 2013: 125)

b. te jalāl-e hun āmārā.

2SG.DIR PN-OBL with come.PST.3SG

(Harzani)

'You came with Jalal.' (Sabzalipur 2013: 132)

In the Harzani dialect of Northern Tāti, the borrowed postposition $-n a$ is also attested in few instances. e.g.

(8) ahmad raz-e ču-un na kar gam könda.

PN garden-OBL wood-PL with house make do.PRS.3SG

'Ahmad makes house with the woods of (trees of) garden.' (Sabzalipur 2013: 122)

The borrowed adposition is used together with the inherited adposition in one sentence which shows that the borrowed postposition has not gained a fixed position in this group. e.g.

(9) man dad=am hun na i hültül-un-u mebodor-am. (Harzani)

1SG.DIR mother=1SG with with this child-PL-OBL take care.PRS-1SG

'I take care of these children with my mother.' (Sabzalipur 2013: 125, 129)

As the data for Northern Tâti is little and we do not have complete information about the usage of native or borrowed postpositions in all the instrumental-related functions, we will not draw the semantic map for this group. 
5.4. TĀLYSHI. The Tālysh region is commonly divided into three general dialect areas: Northern, Central, and Southern (Paul 2011: 18). Mohammadirad and Rasekh-Mahand (2018: 589) have discussed the instrumental marker in Tālyshi. According to them, instrumental marker in Northern Tālyshi is different from that of central and southern Tālyshi, i.e. it is -anda in Northern Tālyshi and $-n a$ in Central and Southern Tālyshi.

Now the question is, has the adposition (i)nan been borrowed into Tāti and Tālyshi with its entire polysemy network? In order to answer this question, we will consider the functions of -inan in the source language, Turkic of Northwest Iran.

5.5. TURKIC. The Turkic or Azari suffix -nan used in Northwest Iran is a variant of the comitative $\&$ instrumental clitic ("with") which in Standard Turkish is -(i)le, itself ultimately derived from a postposition, the form of which is ile in the standard language. In different places in Anatolia, and in the Oghuz dialects of Iran and Azerbaijan, variants of the postposition like ilen, inen, inan, and inay are found. Each of these also has a shorter bound form; so, -nan is an expected form in a dialect which used inan as the postposition. Ultimately, these all come from the adverb and postposition birlä 'together (with)' plus the instrumental case suffix -(i)n. birle is attested in Old Turkic and in the oldest recorded Oghuz and is composed of the independent morpheme bir "one" $+-l a$ which is an old adverb ending. An example of this postposition in Turkic varieties is Ahmad inan gediram 'I am going with Ahmad' in which the proper name Ahmad is governed by the postposition inan. It is used in some shape or other in practically all Turkic languages. Therefore, inan is typical for Turkic varieties spoken in Iran, and also in dialects spoken in East Anatolia. Bulut (2018: 418) writes: "Across the region the instrumental case is $\{+(\mathrm{I}) \mathrm{nAn}\}, \ldots$ " Bulut (ibid) treats it as a case suffix, although it could equally plausibly be considered a postposition. The use of this form as opposed to the functionally equivalent Standard Turkish -ile 'with (instrument and comitative)' is a major isogloss distinguishing the Iran and East Anatolian varieties from Standard Turkish.

We had the adposition questionnaire from 2 Turkic varieties of Iran: Hamedani Turkic where we live, and Khalkhāli Turkic where the Central Tāti of Shāhrud is also spoken. In both these varieties, the postposition -(i)nan meaning with is used for instrumental-related functions and fulfills the similar functions. Thus, we show example sentences from the Turkic variety of Shāhrud. -inan is used in Shāhrudi Turkic for the following functions: instrumental (e.g. 10-a), companion (e.g. 10b), co-participant (e.g. 10-c), manner (e.g. 10-d), material (e.g. 10-e), source (e.g. 10-f), and cause/reason (e.g. 10-g).
(10) a. qāpen
āčār-nan
āš-dəm.
(Shāhrudi)
door key-with open.PST-1SG
'I opened the door with a key.'
$\begin{array}{cll}\text { b. kitāv-i } & \text { uz-inan } & \text { gatti. } \\ \text { book-DEF } & \text { 3sG-with } & \text { bring.IMP.2SG }\end{array}$
'Bring the book with yourself.'
c. man bāji-m-nan sāvāš-dəm.
1SG sister-1SG-with discuss.PST-1SG
'I had an argument with my sister.'
$\begin{array}{cllll}\text { d. bu } & \text { dars-oxumaq-u-nan } & \text { heš } & \text { yera } & \text { yetešmesan. } \\ \text { this } & \text { lesson-read-OBL-with } & \text { no } & \text { place } & \text { NEG.reach.PRS.2SG }\end{array}$
(Shāhrudi)
(Shāhrudi)
'In this way of studying, you won't reach anywhere.' 

e. biz qāteq-i
sut-e-nan
düzaldarux.
(Shāhrudi)
1PL yogurt-DEF milk-OBL-with
make.PRS.1PL
'We make yogurt with the milk.'
$\begin{array}{lllll}\text { f. top-o } & \text { hasan-nan } & \text { al } & \text { ver } & \text { man-a. } \\ \text { ball } & \text { PN-with } & \text { get.IMP.2SG } & \text { give.IMP.2SG } & \text { 1SG-to }\end{array}$
'Take the ball from Hasan and give it to me.'
g. hayat gull-ar-ina(n) sam āl-dum.
yard flower-PL-with poison buy.PST-1SG
'I bought poison for the yard's flowers.'

Figure (6) illustrates boundaries of -(i)nan in the Turkic varieties of Shāhrudi

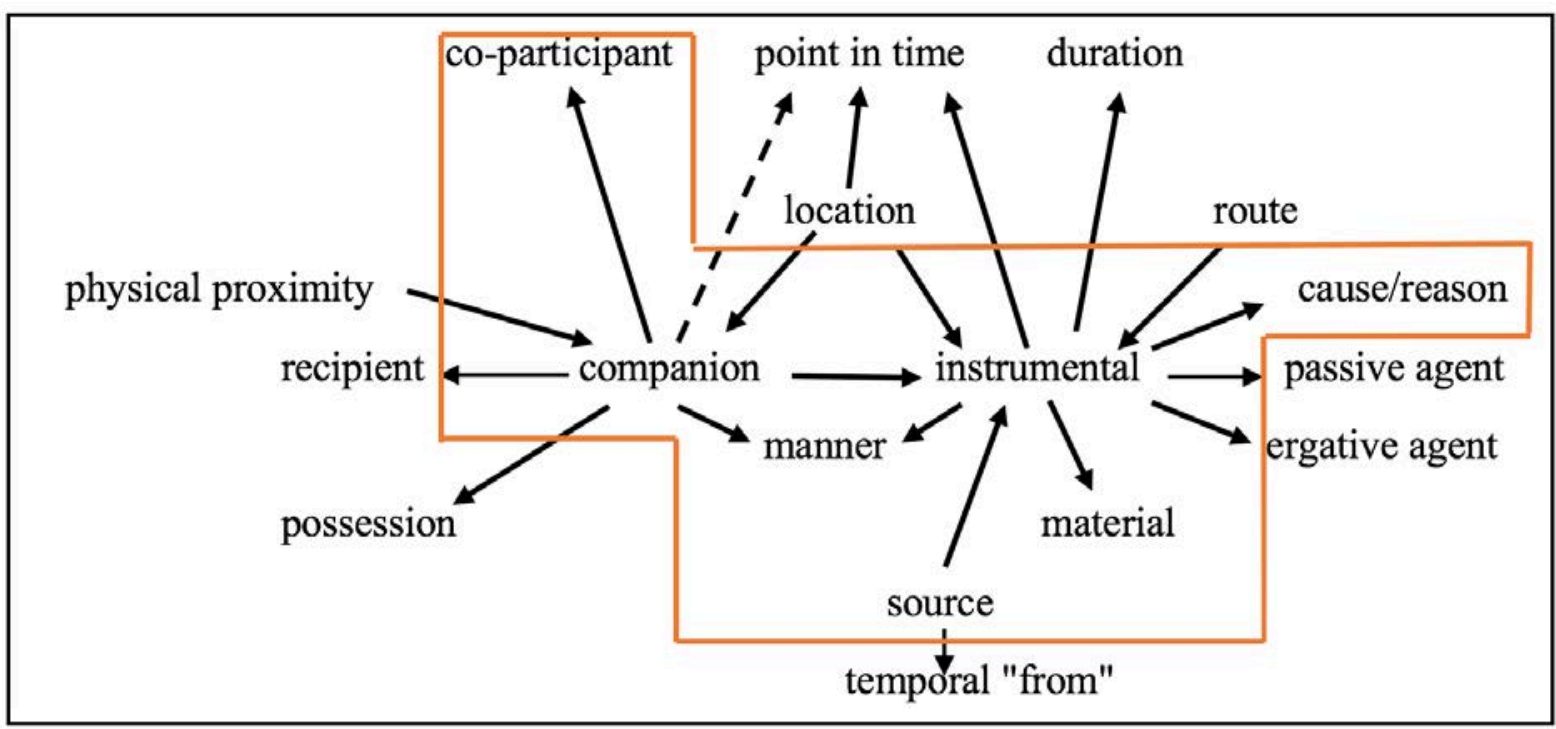

Figure 6. Boundaries of -inan in Turkic varieties of Shāhrudi

6. Discussion and Conclusions. Although the Iranian languages spoken in northwest Iran in provinces such as Zanjān, Qazvin, Ardebil and Markazi are called Tāti by their speakers and others, these languages and dialects have subtle differences with each other. One of these differences is the form and functions of instrumental-related postposition which shows considerable variation through Tâti varieties. While many Tâti varieties use native instrumental postpositions, some have replaced it with borrowed elements. The cross-dialectal variation in the form and functions of instrumental-related postpositions was so unique and interesting that we tried to explore it in more depth in this study.

Turkic-Tātic social setting where the Turkic and Tātic languages have been in contact for a long time has induced borrowing and change at different levels. Typologically, structural morphs are least likely to be traded whereas phonological and syntactic features vary considerably in cross-linguistic availability (Perry 2006). This study explored the result of long contact between Turkic and Tātic languages that took place at morphological and syntactic levels. It was shown that Central and Northern Tāti and Central and Southern Tālyshi have borrowed the postposition "-inan" from the Turkic varieties of Northwest Iran. These dialects are linguistically quite close to each other and are geographically located near one another. Figure (7) demonstrates the results of this study. 


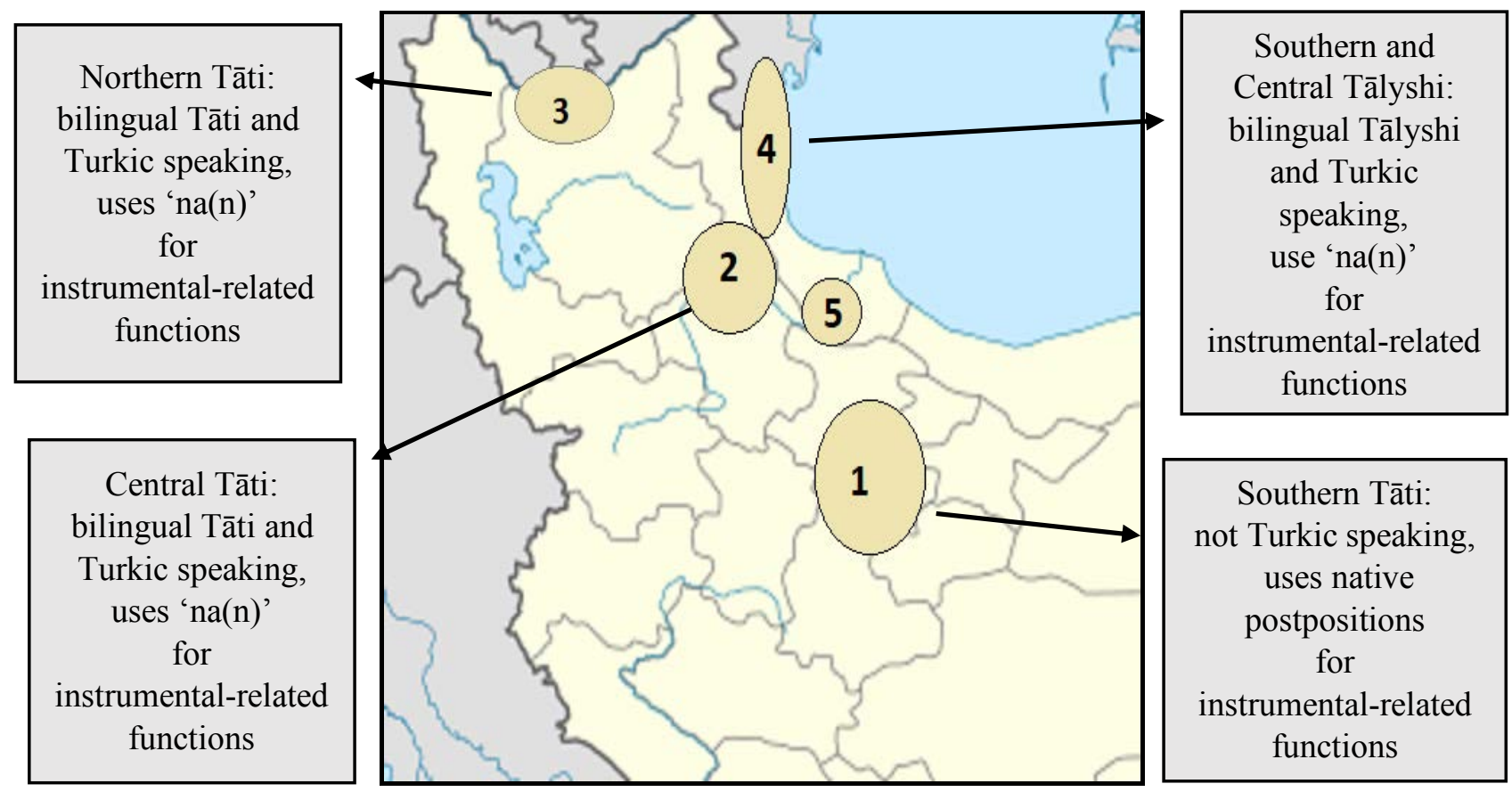

Figure 7. Location of Southern and Central Tāti dialects

Based on the data studied in this research, figure (8) shows a comparison of the functions of instrumental case marker in Shāhrudi Turkic (the red lines) and Central Tāti (the blue lines):

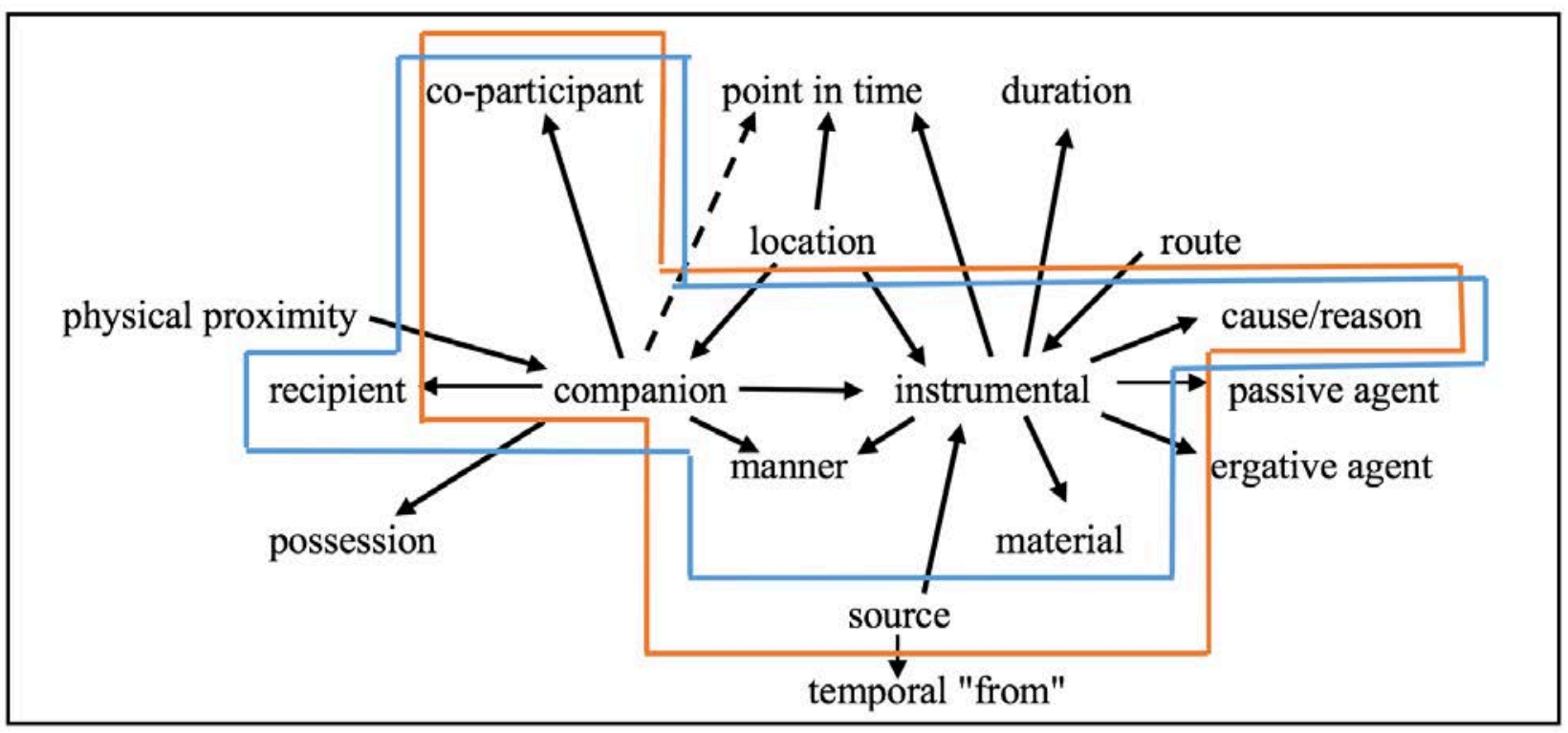

Figure 8. Boundaries of -inan and na(n) in Turkic and Central Tāti respectively

As can be seen in figure (8), most of na(n)'s functions in Shāhrudi dialects of Central Tāti are the same as the Turkic variety spoken in the area. One of the differences between these languages is the "source" function which is not fulfilled with $n a(n)$ in Central Tāti but is among -inan's functions in the Turkic varieties of Northwest Iran. This difference may be attributed to the original 
lost instrumental-related postpositions in the Tâti dialects as the instrumental postpositions in the Southern Tāti dialects does not mark the source function either. Therefore, we see that the new borrowed postposition marks only those functions which were indexed with the lost original postposition. The other difference in figure (8) is regarding the recipient function in the Shāhrudi dialects of Central Tāti which use the borrowed postposition also for marking the recipient function but this function is not observed in the Turkic varieties of the area. This difference may again be attributed to the functions of the original Tāti postpositions which as shown in figure (3), also mark the recipient function at least in Vafsi dialect of Southern Tāti. In sum, the borrowed postposition only marks those functions which were fulfilled with the original postposition native in the Tâti dialects and does not include all the semantic roles of the postposition in the donor language.

In sum, the cross-dialectal variation in using instrumental-related postpositions in Tātic dialects led us to a linguistic phenomenon which is not much common typologically. The borrowing of adpositions such as instrumental-related postposition into Tātic demonstrates an interesting event which is spreading among Tāti dialects as a result of the longstanding contact between Tātic and Turkic dialects of Northwest Iran and sheds light on the nature of the borrowing of functional elements as rare linguistic phenomenon.

$\begin{array}{clll}\begin{array}{c}\text { Abbreviations } \\ \text { Cl }\end{array} & \text { Classifier } & \mathrm{Pl} & \text { Plural } \\ \text { Con } & \text { Continuous } & \text { Pn } & \text { proper name } \\ \text { Cop } & \text { Copula } & \text { Poss } & \text { Possessive } \\ \text { Dir } & \text { Direct } & \text { Prs } & \text { Present } \\ \text { Dur } & \text { durative } & \text { Neg } & \text { Negative } \\ \text { Ez } & \text { Ezafe } & \text { Pst } & \text { Past } \\ \text { Fm } & \text { Feminine } & \text { Pu } & \text { punctual } \\ \text { Imp } & \text { Imperative } & \text { Pvb } & \text { Preverb } \\ \text { Impf } & \text { imperfective } & \text { Ref } & \text { Reflexive } \\ \text { Ind } & \text { Indefinite } & \mathrm{Sg} & \text { Singular } \\ \text { Inf } & \text { infinitive } & 1 \mathrm{Sg} & \text { first person singular } \\ \text { Ipfv } & \text { Imperfect } & 2 \mathrm{Sg} & \text { second person singular } \\ \text { Gen } & \text { genitive } & 3 \mathrm{Sg} & \text { third person singular } \\ \text { Loc } & \text { Locative } & 1 \mathrm{Pl} & \text { first person plural } \\ \mathrm{M} & \text { Masculine } & 2 \mathrm{Pl} & \text { second person plural } \\ \text { Obl } & \text { Oblique } & 3 \mathrm{Pl} & \text { third person plural } \\ \text { Opb } & \text { oblique pronominal } & \mathrm{Subj} & \text { subjunctive } \\ & \text { base II (Benefact.) } & & \end{array}$

\section{References}

Auwera, Johan van der. 2013. Semantic maps: For synchrony and diachrony. In Anna Giacalone Ramat, Caterina Mauri \& Piera Molinelli (eds.), Synchrony and diachrony: A dynamic interface, 153-176. Amsterdam: Benjamins. https://doi.org/10.1075/slcs.133.07auw

Auwera, Johan van der \& Vladimir A. Plungian. 1998. Modality's semantic map. Linguistic Typology 2(1). 79-124. https://doi.org/10.1515/lity.1998.2.1.79

Bulut, Christiane. 2018. The Turkic varieties of Iran. In: Haig, Geoffrey and Geoffrey Khan (eds.) The languages and linguistics of Western Asia. An areal perspective, 398-444. Berlin: De Gruyter. https://doi.org/10.1515/9783110421682-013 
Croft, William. 2003. Typology and universals. Cambridge: Cambridge University Press. https://doi.org/10.1017/CBO9780511840579

Doerfer, Gerhard. 2011. Azerbaijan viii. Azeri Turkish. Iranicaonline. Vol. III, Fasc.3, pp. 245-248.

Field, Fredric W. 2002. Linguistic borrowing in bilingual contexts. Amsterdam: Benjamins. https://doi.org/10.1075/slcs.62

Hagège, Claude. 2010 Adpositions, Oxford: Oxford University Press. https://doi.org/10.1093/acprof:oso/9780199575008.001.0001

Haspelmath, Martin. 2003. The geometry of grammatical meaning: Semantic maps and cross-linguistic comparison. In Michael Tomasello (ed.), The new psychology of language. Vol. 2, 211-242. Mahwah, NJ: Erlbaum. https://doi.org/10.5281/zenodo.831410

Matras, Yaron. 2007. The borrowability of grammatical categories. In Yaron Matras \& Jeanette Sakel (eds.), Grammatical borrowing in cross-linguistic perspective. Berlin: Mouton De Gruyter, 31-74. https://doi.org/10.1515/9783110199192.31

Mohammadirad, Masoud \& Mohammad Rasekh-Mahand. 2017. Instrumental semantic map in Western Iranian languages. STUF 70(4): 579-610. https://doi.org/10.1515/stuf-2017-0025

Narrog, Heiko. 2010. A diachronic dimension in maps of case functions. Linguistic Discovery 8(1). 233254. https://doi.org/10.1349/PS1.1537-0852.A.352

Narrog, Heiko \& Shinya Ito. 2007. Reconstructing semantic maps: The comitative-instrumental area. $\begin{array}{llll}\text { Language Typology } \quad \text { and } & \text { 273-292. }\end{array}$ https://doi.org/10.1524/stuf.2007.60.4.273

Paul, Daniel. 2011. A comparative dialectal description of Iranian Taleshi. Ph.D. dissertation, University of Manchester.

Perry, John. 2001. The Historical Role of Turkish in Relation to Persian of Iran. Iran \& the Caucasus, 5, 193-200.

Perry, John. 2006. Turkic-Iranian contacts I. linguistic contacts. Iranicaonline.

Sabzalipur, Jahāndust. 2013. "Case Marking in Harzandi Language", Collection of papers presented at the First Conference on Iranian Languages, ed. Mehrdād NaghzguyKohan. Tehran: Neviseh Pārsi, Pp. 109-137.

Stilo, Donald. 1981. The Tati Language Group in the Sociolinguistic Context of Northwestern Iran $\begin{array}{llllll}\text { and } & \text { Transcaucasia. } & \text { Iranian } & \text { Studies } & & \text { (3/4). }\end{array}$ https://doi.org/10.1080/00210868108701585

Stilo, Donald. 2018. The Caspian region and south Azerbaijan: Caspian and Tatic. In Geoffrey Haig \& Geoffrey Khan (Eds.) The Languages and Linguistics of Western Asia, An areal perspective. De Gruyter Mouton. 659-824. https://doi.org/10.1515/9783110421682-019

Windfuhr, Gernot L. 1987. "Convergence: Iranian Talyshi and Turkic Azeri," in Elena Bashi, Madhav M. Dshpande, and Peter E. Hook, ed., Select Papers from South Asian Language Analysis 7: Roundtable Conference Held in Ann Arborm Mich., May 17-19, 1985, Bloomington, IN, pp. 385-406.

Yar-Shater, Ehsan. 1969-a. A Grammar of Southern Tati Dialects. The Hague: Mouton.

Yar-Shaater, Ehsan. 1969-b. "The Use of Postpositions in Southern Tati," V. Minorsky Memorial Volume, Tehran University Press, 1969, Pp. 221-55. 